\title{
ВІДТВОРЕННЯ НАЦІОНАЛЬНО МАРКОВАНОЇ ЛЕКСИКИ В ПЕРЕКЛАДІ УКРАЇНСЬКИХ КАЗОК АНГЛІЙСЬКОЮ МОВОЮ
}

Стаття присвячена дослідженню національно маркованої лексики, що іï виокремлено в украӥнських народних казках. Особливу увагу сфокусовано на безеквівалентній лексиці, щз становить труднощі в процесі перекладу англійською, оскільки вона не має відповідників у иій мові. У дослідженні проаналізовано наявні переклади казок, обьрунтовано доцільність використання конкретних перекладацьких трансформацій, запропоновано можливі способи перекладу безеквівалентної лексики, що забезпечують відтворення прагматики оригінальних текстів.

Ключові слова: начіонально маркована лексика, безеквівалентна лексика, прагматика, мова перекладу, трансбормачіі.

Karpenko N., Klavkina M. Rendering of Nationally Marked Vocabulary in Translation of Ukrainian Fairy Tales into the English Language. The article is devoted to the study of nationally marked vocabulary that is identified in Ukrainian folk fairy tales. A fairy tale is viewed as an object of study that accumulates ethnical features of a certain nation and reflects its national identity. Therefore, the problem of translation of fairy tales gets even more complex due to the number of words that do not have equivalents in translation language.

The relevance of the topic is brought about by modern tendencies of the development of intercultural communication in general and by the translation studies in particular. Moreover, the problem of translation of nationally marked language units and rendering their pragmatics into another language is the one which requires further and more precise work, regarding its complexity and lack of extensive studies.

The aim of the research is to find out means of translation of Ukrainian nationally marked language units in English translation of Ukrainian folk fairy tales and prove the relevance of their usage.

Non-equivalent vocabulary was identified in texts of Ukrainian fairy tales and analysed in respect of rendering nationally marked colouring into the English language. The names denoting food, vehicles, drinks, buildings, clothes and containing nationally-specific information were found out in Ukrainian fairy tales and their translations were analysed and compared.

The aim results in solving the tasks as follows: 1) to identify language units containing ethnical component in Ukrainian fairy tales; 2) to compare the variants of translation made by different translators; 3) to find out the most relevant means of translation providing rendering nationally marked component into the English language. 
Карпенко Н. А., Клавкіна М. О. Відтворення національно маркованої лексики в перекладі українських казок...

The findings show that some solutions were not the best ways to express the original cultural-specific charge and other variants were suggested. The research reveals the most frequent ways of translation and the most relevant ones.

Key words: nationally marked vocabulary, non-equivalent vocabulary, pragmatics, translation language, transformations.

\section{Вступ}

Кожна мова - це втілення духу, традицій, вірувань, національної ідентичності конкретного народу. Саме тому особливої уваги потребують дослідження у сфері перекладознавства з урахуванням таких аспектів мови, як її етнічна маркованість і прагматика. Перекладознавство відіграє важливу роль у формуванні мовної картини світу українців у сприйнятті іноземців, оскільки саме перед перекладачами постає проблема відтворення комунікативно-прагматичної спрямованості, інтенцій автора, трансформації лінгвоспецифічних особливостей тексту зі збереженням ідентичності мови оригіналу в перекладі для читачів - представників іншої культури.

Питання особливостей відтворення етнічного компоненту українських казок досліджували у XX сторіччі такі лінгвісти й перекладознавці, як Н. Андрущенко, С. Влахов, І. Голубовська, Т. Жукова, P. Зорівчак, I. Корунець, Н. Кушина, О. Масло, Н. Сопилюк, С. Флорін та ін.

Народна казка $є$ одним зі способів відображення побуту народу, його історії, релігійних і культурних поглядів, мовних, комунікативних та психологічних особливостей, емоційно-оцінних суджень. Це об’єкт акумуляції етнічних особливостей народу. Тож іiі переклад потребує максимальної уваги й відповідальності перекладача з урахуванням особливостей українських реалій, що їх репрезентує безеквівалентна лексика.

Актуальність дослідження зумовлена сучасними тенденціями розвитку міжкультурної комунікації загалом і перекладознавства зокрема. Окрім того, проблема перекладу етнічно маркованих мовних одиниць є однією з таких, що потребує подальшої та більш детальної розробки через їі складність і недостатню кількість вичерпних розвідок у відповідному напрямку.

Мета дослідження - виявити способи перекладу українських національно маркованих мовних одиниць у текстах народних казок англійською мовою та обгрунтувати доцільність їх використання. 
Поставлена мета зумовлює виконання таких завдань: 1) виявити національно марковану лексику в текстах українських народних казок; 2) порівняти наявні переклади українських казок англійською мовою; 3) визначити найбільш доцільні способи відтворення національно маркованої лексики в перекладі англійською мовою.

Для дослідження було обрано переклади, що їх Р. Бейн (Cossack fairy tales, 1894), А. Біленко (Ukrainian folk tales, 1974), I. Желєзнова (Ukrainian folk tales, 1986) виконали англійською мовою. Зазначимо, що з огляду на хронологічні межі здійсення перекладів тексти казок потребують своєрідного «оновлення» з урахуванням змін епохи й сучасних соціально-політичних тенденцій.

\section{Методи дослідження}

Для досягнення мети використано передусім такі методи дослідження: цілеспрямованої вибірки (для виоркемлення національно маркованої лексики); порівняльного й компонентного аналізів (для визначення та порівняння семантичної структури лексем, що містять відповідну прагматику).

\section{Виклад основного матеріалу}

Під час дослідження національно маркованої лексики варто звернути увагу на термін безеквівалентна лексика, що досі не отримав єдиного тлумачення в українській лінгвістиці. Однак мовознавці одностайні в тому, що для перекладу такої лексики складно або й неможливо знайти відповідники в мові перекладу. У зв'язку із цим М. Кочерган говорить про поняття «безеквівалентність» і «лакуна» та зазначає, що в «науковій літературі терміни безеквівалентна лексика і лакуни часто вживаються як синонімічні і трактуються як слова, що відсутні в певній мові» (Кочерган, 1999: 42). Тому перекладачеві доводиться розв'язувати завдання, що заздалегідь не мають відповіді.

Назви страв є групою лексем, що часто не мають прямих відповідників у мові перекладу. У наступному прикладі, зокрема, виявляємо іменники галушки й сало: ... Прийшли додому, чоловік $і$ каже: - Жінко, вари лишень гречані галушки та сито їх із салом затовчи... (Українські народні казки); They went into the house, and the master said: Make us an extra dish of dumplings, wife, and don't spare the fat!... (Ukrainian folk tales, 1986). Іменник галушки перекладено за допомогою англійського відповідника dumplings, що є доречним, однак перекладач 
не відтворив прикметник гречані, що зумовлює часткову втрату повідомлення. Зауважимо, що для перекладу лексеми сало доцільніше було використати транскодування - salo, замість fat, оскільки такий варіант не забезпечує відтворення прагматики оригіналу.

Виявляємо також іменники горілка та паляниия: ...Старі, нічого робити, взяли, поблагословили їх на дорогу, баба надавала їм білих паляниц, спекла порося, пляшку горілки дала - пішли вони... (Українські народні казки); ...It could not be helped, so the parents blessed them, the mother gave them some white bread, a roast pig and a flask of Ukrainian vodka for the road, and away they went... (Ukrainian folk tales, 1986). Під час перекладу було збережено національну специфіку й відтворено іï за допомогою коректно підібраних аналогів, проте переклад слова паляниия не зовсім відповідає основній вимозі відтворення національно маркованої лексики. Видається, що більш доцільно було б використати транслітерацію з експлікацією значення. У такому разі переклад цього слова мав би такий вигляд: palianytsia - the round loaf of bread, made of wheat flour. Щодо перекладу словосполучення пляшка горілки (a flask of Ukrainian vodka), то тут простежуємо вплив російської культури на переклад з метою збереження українського колориту, варто було 6 використати транскодування a flask of Ukrainian horilka.

Рушник $є$ одним із символів українського народу, тому в перекладі це слово має бути відтворено якомога ближче до оригіналу. Також у наведеному нижче прикладі виявляємо іменник на позначення міри відстані - верста, порівн.: ...Зараз вийняла 3-під поли рушник з золотими кіниями та як махне тим змївським рушником, так його надвоє й розрубала: ноги остались тут, а тулуб з головою ізніс дах у будинку і впав за сім верст від будинку... (Українські народні казки); ...And immediately she drew out of the ground a handkerchief with gold borders, and no sooner had she waved this serpentine handkerchief, than Ivan fell asunder into two pieces. His legs remained where they were, but his trunk with his head disappeared through the roof, and fell seven miles away from the house... (Cossack fairy tales and folk tales, 1894). Те, що Р. Бейн не зберігає слово верста в перекладі, а замінює його більш знайомою англійцям мірою - милею, видається доцільним. А от етнічно марковане слово рушник взагалі втрачає свою маркованість у перекладі, оскільки перекладач добирає відповідник handkerchief, що не є доречним. Варто було б використати транскодування з експлікацією 
значення: rushnyk - it is a long piece of cloth, decorated with any kind of embroidered or woven ornament, traditionaly used in Ukrainian rites.

Також фіксуємо вживання іменника віз, що привертає до себе увагу, оскільки відображає традиційний у давні часи засіб пересування - кінь з возом - та викликає труднощі в перекладі, порівн.: ...Піди зараз же до типки та попроси конячку з возом... (Українські народні казки). А. Біленко й І. Желєзнова відповідно передають цю мовну одиницю так: ... Go back to the linden right away and ask it for a horse and cart... (Ukranian folk tales, 1974),... Go back at once and tell the lime tree that you want a horse and a cart... (Ukrainian folk tales, 1986). Перекладачі добирають англійський іменник cart, що не відтворює прагматики оригіналу. Варто було б подати транслітерацію цього слова й пояснення його значення: voz (a kind of vehicle with four wheels, harnessed with a horse or an ox, for transportation of any type of load), що забезпечило б збереження національної специфіки.

На початку казки «Колобок» показано двох дійових осіб, що характерні майже для усіх українських народних казок, - дід та баба. Також звертаємо увагу на іменник колобок - виріб з тіста: Жили собі дід і баба та дожились уже до того, що й хліба нема. Дід і каже: - Бабусю! Спекла 6 ти колобок!... (Українські народні казки). А. Біленко перекладає ці одиниці так: Once upon a time there lived an Old Man and an Old Woman. They were so poor that they did not have a crust of bread in the house. One day the man went after the woman: Old Woman, bake mе a johnnycake... (Ukranian folk tales, 1974). Щодо перекладу перших двох одиниць, то запропоновані варіанти є усталеними й доречними. Щодо третього слова (колобок) можна сказати, що воно відтворено не зовсім вдало, адже, колобок - ие невеликий круглий хлібець (Великий тлумачний словник), а обраний варіант johnnycake - корж (амер. маїсовий; австрал. - пшеничниц̆) свідчить про те, що такий переклад не є коректним, оскільки суперечить подальшій ідеї казки (порівн., корж - ие плоский круглої форми виріб із прісного тіста (Великий тлумачний словник)).

Переклад І. Желєзнової виявився більш удалим, оскільки слово bun перекладається як здобна булочка, кекс, а це означає, що такий виріб може бути круглої форми: Once upon a time there lived an old man and an old woman who were very poor and had nothing at all to their name. And they kept getting poorer and poorer till there was nothing left to 
eat in the house, not even bread. Said the old man: Do bake us a bun, old woman!... (Ukrainian folk tales, 1986).

У наступному прикладі було виявлено дві мовні одиниці, що містять етнічний складник, оскільки є реаліями українського життя: - От, бабусю, піди в хижку та назмітай у засіку борошения, то й буде колобок... (Українські народні казки).

Порівняймо переклад А. Біленко (...Go to the pantry, sweep up some flour in the bin, and there you'll have something to bake the johnnycake with... (Ukranian folk tales, 1974)) і переклад I. Желєзнової (...If you scrape out the flour-box and sweep out the bin, you'll have enough flour... (Ukrainian folk tales, 1986)).

У цьому разі недоречно було робити заміну слова хижка нейтральними словами комора чи коробка для борошна, оскільки в процесі перекладу має бути відтворена їхня національна маркованість. Варто було б зробити це за допомогою транслітерації з експлікацією, оскільки слово хижка зараховують до безеквівалентної лексики. Доречніше було б перекласти так: Old woman, go the khyzhka (this is one of the types of buildings in the yard, in which it was possible to sleep in the summer and to store different types of cereals and flour) and sweep out the bin, you'll have enough flour.

В українській народній казці «Нещасний Данило» наявні мовні одиниці на позначення назви закладу для відпочинку - шинку й відповідної професії - шинкаря, порівн.: ...Гляди, їдь до того шин$\kappa у$, де і вперше був, та як станеш враниі вмиватися, проси шинкаря, щзоб він бив тебе иим ременем, як дужче, подовж спини... (Українські народні казки, 1991).

Р. Бейн і А. Біленко перекладають ці мовні одиниці так: ...Go to that inn where thou didst go before, and early next morning, whilst thou art bathing, bid the innkeeper beat thee with all his might on the back with this chain... (Cossack fairy tales and folk tales, 1894), ...Go to the same inn as before. Stay the night there, and early next morning, when you will be washing yourself, ask the innkeeper to beat you across the back with this belt as hard as he can... (Ukranian folk tales, 1974). У словнику подано таке визначення слова іпn - готель (за містом); кафе; постоялий двір (ABBYY Lingvo Live). Читач може знати лише перше значення цього слова, що є найбільш поширеним, тому це може спричинити хибне сприйняття та викликати неправильні асоціації в нього, оскільки 
шинок - ие невеликий заклад, де продавалися на розлив спиртні напої; корчма (Великий тлумачний словник). Також, ураховуючи основний принцип перекладу народних казок, а саме необхідність збереження національно-маркованих мовних одиниць, варто було скористатися транскрипцією з поясненням: shynok - it is a place, where people could eat and drink alcohol, something like café. Це стосується і перекладу слова шинкар. Перекладачеві варто було б зберегти його етнічність й апелювати саме до національного колориту.

Українці завжди славилися своїми традиціями й звичаями, особливо весільними. У казці «Яйце-райце» трапляється декілька згадувань про такі традиції та декілька мовних одиниць, серед яких слова шишки й молодиці: ... От перед весіллям, увечері, кличуть на шишки молодиць... (Українські народні казки).

Перекладачі відтворили ці лексичні одиниці так: а) переклад Р. Бейна: ... Now the evening before the wedding they heard a young damsel crying Shishki in the streets... (Cossack fairy tales and folk tales, 1894); б) переклад А. Біленко: ... On the evening before the wedding, all the village girls were invited to the bride's house to make shishki (wedding cakes)... (Ukranian folk tales, 1974); в) переклад I. Желєзнової:... On the eve of the wedding all the young girls of the village, the Maid among them, were invited to the groom's house to bake buns... (Ukrainian folk tales, 1986).

У перекладах Р. Бейна й А. Біленко лексична одиниця шишки відтворена вдало завдяки тому, що перекладачі спочатку подають транслітерацію, а потім пояснення про те, що саме називають шишками. Р. Бейн робить це у виносках, а А. Біленко одразу в тексті. I. Желєзнова, на жаль, не зберігає етнічності й робить генералізацію, перекладаючи як buns.

\section{Висновки}

Через наповненість казок безеквівалентною лексикою здійснити ідентичну їх інтерпретацію іноземною мовою неможливо. Однак фахівець повинен майстерно використати весь можливий спектр способів перекладу, поєднуючи їх з фоновими знаннями та мовною практикою. У проаналізованих прикладах найбільш частотними й вдалими способами перекладу вважаємо транскодування з тлумаченням слів у виносках або ж описовий переклад. Також можливий переклад за допомогою генералізації, однак тут, безсумнівно, втрачається національно маркований складник досліджуваних одиниць. 
Перспективу подальших досліджень убачаємо в розробці теоретичного інструментарію перекладу національно маркованої лексики й укладанні словника безеквівалентної лексики.

\section{ЛІТЕРАТУРА}

1. Бусел, В. Т. (Ред.) (2007). Великий тлумачний словник української мови (2007). Київ: Ірпінь: ВТФ Перун. 2. Дунаєвська Л. (Ред.) (1991). Українські народні казки. Київ: Веселка. 3. Кочерган, М. П. (1999). До питання про безеквівалентну лексику і лакуни та способи їх компенсації. Проблеми зіставної семантики (с. 42-45). Київ: б. в. 4. Украйнські народні казки. Узято з http://nashakazka.org.ua/. 5. АВВYY Lingvo Live. Узято з https://www.lingvolive.com/ru-ru/translate/en-uk/inn. 6. Cossack fairy tales and folk tales (1894). (R. Nisbet Bain, trans.). N. Y.: A. L. Burt Company. 7. Ukranian folk tales (1974). (A. Bilenko, trans.). Kyiv: Dnipro publishers. 8. Ukrainian folk tales (1986) (I. Zheleznova, trans.). Kyiv: Dnipro publishers.

\section{REFERENCES}

1. Busel, V. T. (Ed.) (2007). Velykyi tlumachnyi slovnyk ukrainskoi movy [Big dictionary of the Ukrainian language]. Kyiv: Irpin : VTF Perun [in Ukrainian]. 2. Dunaievska, L. (Ed.) (1991). Ukrainski narodni kazky [Ukrainian folk tales]. Kyiv: Veselka [in Ukrainian]. 3. Kochergan, M. P. (1999). Do pytannia pro bezekvivalentnu leksyku i lakuny ta sposoby ih kompensatsii [The issue of non-equivalent vocabulary and lakunas and means of their compensation]. Problemy zistavnoi semantyky - Problems of comparative semantics (pp. 42-45). Kyiv: b. v. [in Ukrainian]. 4. Ukrainski narodni kazky - Ukrainian folk tales. Retrieved from http://nashakazka.org.ua/ [in Ukrainian]. 5. ABBYY Lingvo Live. Retrieved from https://www.lingvolive.com/ru-ru/translate/en-uk/inn [in English]. 6. Cossack fairy tales and folk tales (1894). (R. Nisbet Bain, trans.). N. Y.: A. L. Burt Company [in English]. 7. Ukranian folk tales (1974). (A. Bilenko, trans.). Kyiv: Dnipro publishers [in English]. 8. Ukrainian folk tales (1986) (I. Zheleznova, trans.). Kyiv: Dnipro publishers [in English].

Карпенко Наталія Анатоліївна - кандидат філологічних наук, доцент кафедри філології, перекладу та мовної комунікації, Національна академія Національної гвардії України; майдан Захисників України, 3, м. Харків, 61168, Україна.

Tel.: +38-098-445-17-24

E-mail: karpenko_nataliya08@ukr.net

orcid.org/0000-0003-2922-0384

Karpenko Nataliia Anatoliivna - Ph.D. in Philology, Associate Professor at the Department of Philology, translation and lingual communication, National academy of the National Guard of Ukraine; Zakhysnykiv Ukrainy square. 3, Kharkiv, 61168, Ukraine.

Клавкіна Марія Олександрівна - магістр гуманітарного факультету, Національна академія Національної гвардії України; майдан Захисників України, 3, м. Харків, 61168, Україна. 
Klavkina Mariia Oleksandrivna - Master Student at the Faculty of Humanities, National academy of the National Guard of Ukraine; Zakhysnykiv Ukrainy square. 3, Kharkiv, 61168, Ukraine.

Надійшла до редакції 03 серпня 2020 року

\section{CITATION}

ДСТУ 8302:2015: Карпенко Н. А., Клавкіна М. О. Відтворення національно маркованої лексики в перекладі українських казок англійською мовою. Лінгвістичні дослідження: зб. наук. пр. Харк. нац. пед. ун-ту імені Г. С. Сковороди. Харків, 2020. Вип. 53. С. 76-84. DOI: https://doi.org/10.34142/23127546.2020.53.07

AРА: Карпенко, Н. А., \& Клавкіна, М. О. (2020). Відтворення національно маркованої лексики в перекладі українських казок англійською мовою. Лінгвістичні дослідження, 53, 76-84. DOI: https://doi.org/10.34142/23127546.2020.53.07 